\title{
Effect of oceanographic conditions on the winter movements of rockhopper penguins Eudyptes chrysocome chrysocome from Staten Island, Argentina
}

\author{
Andrea Raya Rey ${ }^{1, *}$, Phil Trathan ${ }^{2}$, Klemens Pütz ${ }^{3}$, Adrián Schiavini ${ }^{1}$ \\ ${ }^{1}$ Consejo Nacional de Investigaciones Científicas y Técnicas, Centro Austral de Investigaciones Científicas, \\ Bernardo Houssay 200, (V9410BFD) Ushuaia, Tierra del Fuego, Argentina \\ ${ }^{2}$ British Antarctic Survey, Natural Environment Research Council, High Cross, Madingley Road, Cambridge CB3 0ET, UK \\ ${ }^{3}$ Antarctic Research Trust, PO Box 685, Stanley FIQQ 1ZZ, Falkland Islands, South Atlantic
}

\begin{abstract}
We used Argos satellite transmitters to monitor the movement and oceanographic habitats used by rockhopper penguins Eudyptes chrysocome chrysocome during their winter dispersal from Staten Island, Argentina, for 2002 (n = 10) and 2003 ( $\mathrm{n}=15)$. In both years penguins concentrated their activities to shallow and highly productive waters with temperatures ranging from 5 to $8^{\circ} \mathrm{C}$. However, analysis of migration patterns, in conjunction with remotely-sensed sea surface temperature (SST) and chlorophyll a (chl a) concentration data, showed that habitat use and movement were substantially different for the 2 years. Both years were characterised by different oceanographic conditions; comparison of SST revealed colder temperatures in 2002 than the long-term average, while temperatures in 2003 were not significantly different from average conditions. The movement of rockhopper penguins differed between years: penguins migrated to the same general locations but used a larger number of foraging areas in 2002. They also spent less time travelling than in 2003. Moreover, we also found differences in adult survival or return rate and breeding success between years. Consequently, we conclude that during colder winters with more heterogeneous oceanographic conditions (e.g. 2002), penguins are better able to find enough food to achieve body condition for the following breeding season.
\end{abstract}

KEY WORDS: Eudyptes chrysocome chrysocome · Oceanographic conditions · Geographic information system $\cdot$ Foraging $\cdot$ Winter dispersal

Resale or republication not permitted without written consent of the publisher

\section{INTRODUCTION}

Marine resources are distributed heterogeneously in space and time, and are generally related to spatial heterogeneity in physical, chemical and bathymetric features of the marine environment (Guinet et al. 2001, Nel et al. 2001, Jahncke et al. 2005). Factors affecting the environment, as perceived by a predator, are generally numerous and complex, and they act in a variety of temporal and spatial scales (Trathan \& Croxall 2004). Thus, the distribution of seabirds is influenced by scale-dependent processes and constrained by energetic considerations (Guinet et al. 2001, Hyrenbach et al. 2002). Consequently, knowledge about the level of variability in the physical, biological and anthropogenic environment is important when studying the foraging behaviour of marine predators (Trathan \& Croxall 2004, Ladd et al. 2005), whether they are marine mammals, seabirds, turtles or fish (Daunt et al. 2003). An abundant literature exists on how oceanography influences some of these organisms, how they relate to physical and biological fea- 
tures of their habitat and how oceanographic variability affects life-history parameters (Brodie et al. 1978). However, for organisms such as seabirds and marine mammals, some of these influences are only recently becoming apparent as our ability to follow individuals, particularly during non-breeding seasons, develops (Trathan \& Croxall 2004).

Studies of the at-sea ecology of top predators indicate that their distribution, abundance and survival rate and/or breeding success are related to oceanographic features and primary production (Trathan et al. 1996, Inchausti et al. 2003, Jenouvrier et al. 2003, 2005, Bertram et al. 2005, Forcada et al. 2006). Moreover, many recent changes, particularly in population levels, may be attributed to climate variability (Croxall et al. 2002). However, such relationships with the environment are likely to be proxies for more fundamental tropho-dynamic processes. For example, long-term changes in the physical environment in the Antarctic Peninsula region have had a significant effect upon Antarctic krill Euphausia superba, a keystone species in the Antarctic food web (Trathan et al. 2003, Atkinson et al. 2004), which in turn has impacted upper trophic level species (Trathan et al. 2006). Similarly, changes in foraging areas have been observed in the grey-headed albatross Diomedea chrysostoma and the wandering albatross Diomedea exulans and attributed to anomalies in sea surface temperatures (warm conditions), which have also impacted breeding success (Xavier et al. 2003); these changes are almost certainly due to changes in the underlying food web. Elsewhere, decreases in seabird numbers have been associated with anomalous sea surface temperature conditions (Barbraud \& Weimerskirch 2001, Frederiksen et al. 2004). Also, warmer seasonal conditions sometimes associated with climatic processes such as El Niño events are thought to have had a negative impact upon the reproductive success in some seabirds (Schreiber 2001, Inchausti et al. 2003).

Changes in the environment of the Southern Ocean are now well established and have been associated with population changes of various marine predators (Jenouvrier et al. 2003, 2005). Over much of their range, the populations of Eudyptes penguins have undergone considerable declines; for example, populations of the once most numerous rockhopper penguin Eudyptes chrysocome declined by up to $90 \%$ in some locations (Cunningham \& Moors 1994, Pütz et al. 2003). Consequently, studying the oceanographic parameters within the foraging areas of these penguins during their winter dispersal is essential if we are to understand how the physical environment influences penguin ecology, their interactions with prey and their population trends.

In this study we investigated the foraging areas of southern rockhopper penguins Eudyptes chrysocome chrysocome that breed on Staten Island, Argentina, from March to July, 2002 and from March to August, 2003, during part of their winter dispersal. The aims of this study were: (1) to analyse the foraging range and core areas used by southern rockhopper penguins during winter in relation to sea surface temperature (SST), chl $a$ and bathymetry, (2) to analyse the oceanographic conditions against long-term averages for the study area and (3) to study the spatial (travelling and foraging zones) and temporal (years and months) variability of the SST and chl $a$ in these areas.

\section{MATERIALS AND METHODS}

Satellite telemetry. Adult southern rockhopper penguins that breed at Franklin Bay (54 $\left.50^{\prime} \mathrm{S}, 64^{\circ} 40.5^{\prime} \mathrm{W}\right)$, Staten Island, were studied in 2002 and 2003. Penguins were captured after moult at their breeding colonies and equipped with Argos satellite transmitters in mid to late March $2002(\mathrm{n}=9)$ and $2003(\mathrm{n}=15)$, and their movements were studied during their winter dispersal. When captured, the penguins were weighed and bills measured to determine their gender (Hull 1996). All satellite transmitters were mounted on the dorsal midline as distal as possible without impairing the preen gland. The transmitters were attached with waterproof black tape (Tesa, Beiersdorf) and 2-component neoprene glue (Deutsche Schlauchbootfabrik), (Wilson et al. 1997). All devices were covered with a layer of quick epoxy (Loctite ${ }^{\circledR} 3430$ ) to prevent the birds from removing the tape with their beaks. The attachment process took less than 20 min per bird.

The KiwiSat 101 satellite transmitters (Sirtrack) measured $130 \times 35 \times 20 \mathrm{~mm}$ and shaped hydrodynamically (Bannasch et al. 1994). The satellite transmitters were powered by 2 AA lithium cells and weighed approximately $100 \mathrm{~g}$, equivalent to about $5 \%$ of the mean penguin body mass of $2.0 \pm 0.2 \mathrm{~kg}$. To reduce hydrodynamic drag (Wilson et al. 2004), the flexible antenna $(170 \times 3 \mathrm{~mm})$ was positioned at $45^{\circ}$ to the rear of the device.

To extend the battery life, devices were programmed to transmit with a duty cycle of $6 \mathrm{~h}$ on and $18 \mathrm{~h}$ off with a repetition period of $60 \mathrm{~s}$; the transmitters were also equipped with a saltwater switch that prevented transmission under water. All transmitters were switched on at 22:00 h local time (GMT minus $3 \mathrm{~h}$ ). Positional data obtained from Argos (Collecte Localisation Satellites) were classified according to the quality of the location fix, with location classes $0,1,2$ and 3 providing accuracies of $>1,<1 \mathrm{~km},<350$ and $<150 \mathrm{~m}$, respectively (Argos 1996, p 176). All satellite transmitter locations were filtered using a 2-stage speed filter (McConnell et al. 1992) to remove migration speeds exceeding $9 \mathrm{~km}$ 
$\mathrm{h}^{-1}$ (based on the distance and the time elapsed between 2 consecutive locations).

Oceanographic data. To determine the environmental and oceanographic characteristics of the location where the penguins foraged, we used monthly composite images of remotely-sensed, advanced very high resolution radiometer (AVHRR) sea surface temperature (SST) data and monthly composite images of remotely-sensed ocean colour ( $\mathrm{chl}$ a) data. SST data (4.5 km resolution) were obtained from moderate resolution imaging spectroradiometer (MODIS) Ocean NASA for both study years. Chl a data were obtained from MODIS Ocean NASA for 2003 (4.5 km resolution) and from SeaWIFS (Sea-viewing Wild Field-of-view Sensor) for 2002 (9 $\mathrm{km}$ resolution). We also used images of long-term climatology to evaluate temporal variability i.e. SST: NOAA Pathfinder dataset $(5 \mathrm{~km}$ resolution), monthly averages between 1985 and 2003 and chl a: SeaWIFS dataset (9 $\mathrm{km}$ resolution), monthly averages between 1998 and 2004. Oceanic fronts were identified in water masses with temperatures $>1.35^{\circ} \mathrm{C}$ (Moore et al. 1997) using gradient analysis within an area ca. $30 \times 15 \mathrm{~km}$.

Bathymetry data were obtained (ETopo Digital Maps) at a spatial resolution of 2' (latitude and longitude). The bathymetric regime was subdivided as follows: continental shelf waters $(<200 \mathrm{~m})$, shelf slope (200 to $2000 \mathrm{~m}$ ) and oceanic (>2000 m). Although sea surface temperature, chl a concentration and bathymetry may co-vary, we considered them separately in our analysis.

Data treatment and spatial analysis. All data and images were incorporated into ArcGis 9.1 (ESRI) and projected into a Lambert Equal-area Azimuthal (South Pole) projection. Statistical analysis was performed using Minitab 14 (Minitab).

For each year, we produced monthly foraging kernel grids for all penguins in order to characterise their spatial distribution. We calculated combined utilization grids with the kernel density function in the spatial analyst extension of ArcGis 9.1 with a search radius of $50 \mathrm{~km}$ (ca. $5000 \mathrm{~km}^{2}$ ) and an output cell size of $5 \mathrm{~km}^{2}$. We categorized kernel density grids into $4 \mathrm{sep}$ arate percentile regions corresponding to the 25, 50, 75 and $95 \%$ of the density of position estimates, where the $25 \%$ was the least used and the $95 \%$ was the kernel with the highest density. We considered that the $25 \%$ kernel reflected a foraging area that also included considerable migratory activity, and that the areas comprising the 50, 75 and $95 \%$ kernels were core areas or foraging grounds. These kernel grids were then converted into polygons for the different percentile categories to perform further analysis. For certain analyses, we divided the whole study period into 2 phases: late autumn (March to May) and winter (June to July or August).
To characterise the spatial distribution of the penguins in terms of oceanographic parameters, we overlaid the monthly foraging kernel polygons with SST, chl $a$ and bathymetry images; these were then statistically compared. The same procedure was applied to characterise the temporal distribution by months for the long-term data of each oceanographic parameter. Comparisons between long-term and monthly data averages (SST, chl a) were made using a paired $t$-test. Temporal (month) and spatial (\% kernel) distribution analysis within and between years was performed using repeated measure hierarchical ANOVA. Tests for the effects of year and month were based on the residuals for the between-map-variation (i.e. variation between the means in the year $\times$ month partitioned into the contribution from years and months). Tests for effects of kernels and interactions with year and month used the residual for variation within maps (i.e. each combination of year $\times$ month partitioned into contributions from kernel polygons, years, months and their interactions). Also, to detect potential trends, we partitioned variation between months and kernels into linear and non-linear components. The data were logtransformed due to the large range of bathymetry means.

Foraging tracks were also examined to determine whether foraging areas were located within sharp gradients of SST, characteristic of oceanic fronts. Monthly kernel polygons were overlaid with the corresponding gradient image, the numbers of cells with gradients in each polygon were counted and the percentage of the total number of cells inside each polygon calculated.

\section{RESULTS}

\section{Satellite tracking}

Rockhopper Eudyptes chrysocome chrysocome and Magellanic Spheniscus magellanicus penguins are known to bite and break their feathers in order to remove devices attached to their backs (Wilson et al. 1997, Pütz et al. 2002). This was confirmed when we sighted some penguins that we had equipped with satellite transmitters during the previous season. This behaviour would account in some cases for the reduced temporal coverage of our Argos tracking devices. This observation also allowed us to confirm that over-winter survival of our study birds was not impaired by long-term attachments.

The mean weight of tracked penguins were: females: $1.8 \pm 0.3 \mathrm{~kg}$; males: $2.1 \pm 0.2 \mathrm{~kg}$. The mean bill depths and lengths were: females: $18.5 \pm 0.9 \mathrm{~mm}$ and $38.2 \pm$ $2.6 \mathrm{~mm}$; males: $21.7 \pm 0.8 \mathrm{~mm}$ and $43.4 \pm 1.8 \mathrm{~mm}$. 
Table 1. Eudyptes chrysocome chrysocome. Summary of data for 2002 and 2003 from satellite transmitters attached to rockhopper penguins from Staten Island. Minimum distance = the sum of all distances between consecutive positions. Calculation of travel speed includes time spent underwater between 2 positions. Dates given as dd/mm/yy

\begin{tabular}{|c|c|c|c|c|c|c|}
\hline Penguin & Sex & $\begin{array}{l}\text { Start of } \\
\text { migration }\end{array}$ & $\begin{array}{c}\text { Transmission } \\
\text { period } \\
\text { (d) }\end{array}$ & $\begin{array}{c}\text { Max. distance } \\
\text { to colony } \\
(\mathrm{km})\end{array}$ & $\begin{array}{l}\text { Min. distance } \\
\text { covered } \\
(\mathrm{km})\end{array}$ & $\begin{array}{l}\text { Mean trave } \\
\text { speed } \pm \mathrm{SD} \\
\quad\left(\mathrm{km} \mathrm{h}^{-1}\right)\end{array}$ \\
\hline \multicolumn{7}{|l|}{2002} \\
\hline Paul & M & $23 / 04 / 02$ & 59 & 2006 & 3509 & $3.4 \pm 1.7$ \\
\hline Andrea & $\mathrm{F}$ & $24 / 03 / 02$ & 9 & 429 & 596 & $4.0 \pm 1.3$ \\
\hline Discoverer & M & $24 / 03 / 02$ & 10 & 339 & 453 & $3.3 \pm 1.6$ \\
\hline Christopher & $\mathrm{M}$ & $24 / 03 / 02$ & 82 & 394 & 2514 & $2.3 \pm 1.6$ \\
\hline Fyjimo & M & $24 / 03 / 02$ & 121 & 411 & 4064 & $2.9 \pm 2.0$ \\
\hline Rob & M & 24/03/02 & 120 & 863 & 4764 & $4.0 \pm 2.3$ \\
\hline Polar Star & M & $25 / 03 / 02$ & 9 & 397 & 644 & $4.8 \pm 2.1$ \\
\hline Sabra & $\mathrm{F}$ & $25 / 03 / 02$ & 14 & 434 & 749 & $4.3 \pm 2.4$ \\
\hline Glynn & $\mathrm{F}$ & $26 / 03 / 02$ & 17 & 260 & 459 & $1.9 \pm 1.1$ \\
\hline \multicolumn{7}{|l|}{2003} \\
\hline Elisabeth & $\mathrm{F}$ & $21 / 03 / 03$ & 44 & 1020 & 2304 & $4.6 \pm 2.8$ \\
\hline The Boss & M & $22 / 03 / 03$ & 10 & 400 & 511 & $4.4 \pm 1.6$ \\
\hline Katabatic & M & $22 / 03 / 03$ & 91 & 170 & 1662 & $1.6 \pm 1.8$ \\
\hline Otto von Guericke & M & $22 / 03 / 03$ & 32 & 206 & 1016 & $2.5 \pm 1.9$ \\
\hline Steffen & M & $22 / 03 / 03$ & 61 & 143 & 1420 & $2.0 \pm 1.5$ \\
\hline Wagner & $\mathrm{F}$ & $22 / 03 / 03$ & 35 & 253 & 621 & $1.5 \pm 1.3$ \\
\hline Werner F. & M & $22 / 03 / 03$ & 146 & 537 & 5281 & $3.4 \pm 2.1$ \\
\hline Anjali & $\mathrm{F}$ & $23 / 03 / 03$ & 12 & 329 & 531 & $3.8 \pm 1.2$ \\
\hline Toni & M & $23 / 03 / 03$ & 6 & 229 & 251 & $4.6 \pm 2.1$ \\
\hline Willibald & M & $23 / 03 / 03$ & 12 & 316 & 483 & $4.0 \pm 1.9$ \\
\hline Chrisali & $\mathrm{F}$ & $23 / 03 / 03$ & 59 & 334 & 1342 & $1.9 \pm 1.8$ \\
\hline Danny & $\mathrm{F}$ & $23 / 03 / 03$ & 69 & 344 & 1587 & $1.9 \pm 1.5$ \\
\hline Kathy & $\mathrm{F}$ & $23 / 03 / 03$ & 61 & 173 & 1731 & $2.3 \pm 1.9$ \\
\hline Norbert & $\mathrm{F}$ & $23 / 03 / 03$ & 68 & 403 & 1399 & $2.1 \pm 1.9$ \\
\hline Prince Madoc & $\mathrm{F}$ & $24 / 03 / 03$ & 53 & 218 & 1462 & $2.2 \pm 1.7$ \\
\hline
\end{tabular}

The mean number of locations received per duty cycle was $12.3 \pm 4.3$ uplinks. Positions were obtained from each adult from 9 to $121 \mathrm{~d}$ in 2002 and from 6 to $146 \mathrm{~d}$ in 2003. Overall the foraging area extended from $50^{\circ} \mathrm{S}$ to the west of the Falkland Islands (Malvinas) to $62^{\circ} \mathrm{S}$ north of the South Shetland Islands, and from $92^{\circ} \mathrm{W}$ in the Pacific to $49^{\circ} \mathrm{W}$ in the Scotia Arc. The mean maximum distances to the colony were $615 \pm$ $548 \mathrm{~km}$ in 2002 and $338 \pm 217 \mathrm{~km}$ in 2003. The individual values for each bird are summarised in Table 1, and the numbers of uplinks and birds per month are presented in Table 2. The mean minimum distances covered were $1972 \pm 1752 \mathrm{~km}$ in 2002 and $1440 \pm$

Table 2. Eudyptes chrysocome chrysocome. Number of birds tracked and uplinks received for each month during winters of 2002 and 2003

\begin{tabular}{|llrrrrrr|}
\hline Year & & Mar & Apr & May & Jun & Jul & Aug \\
\hline 2002 & Birds & 9 & 9 & 4 & 4 & 2 & \\
& Uplinks & 774 & 1286 & 1015 & 812 & 365 & \\
2003 & Birds & 15 & 14 & 9 & 3 & 1 & 1 \\
& Uplinks & 1749 & 3654 & 2205 & 478 & 305 & 67 \\
\hline
\end{tabular}

$1211 \mathrm{~km}$ in 2003, while birds migrated at mean speeds of $3.1 \pm 0.9 \mathrm{~km} \mathrm{~h}^{-1}$ and $2.8 \pm 1.1 \mathrm{~km} \mathrm{~h}^{-1}$ in 2002 and 2003, respectively. The overall foraging areas (minimum convex polygon enclosing all points) were $839111 \mathrm{~km}^{2}$ in 2002 and $625805 \mathrm{~km}^{2}$ in 2003. The difference in areas for the 2 years was mainly due to the migration of 1 bird that migrated in 2002 far into the Pacific. Also, in 2002 the birds concentrated their activities (based on the $50 \%$ kernel) in a larger area (33 $\left.386 \mathrm{~km}^{2}\right)$ than in $2003\left(14790 \mathrm{~km}^{2}\right)$. Moreover, in 2002 the penguins not only used a larger core area, but they also used more areas i.e. 6 core areas in 2002 and 2 in 2003 (Figs. 1 \& 2)

Kernel densities were used to characterize the spatial distribution of the penguins in terms of oceanographic features. Travelling and core areas differed as the winter progressed, and some differences between years were apparent. In 2002, the penguins left the colony and proceeded in different directions: south, north and northeast. During late autumn (March to May), the penguins foraged mainly in 3 areas: near the Atlantic coast of Tierra del Fuego, north of South Shetland Island and within the Antarctic Polar Frontal Zone (Fig. 1a). However, during the winter (June to July), 

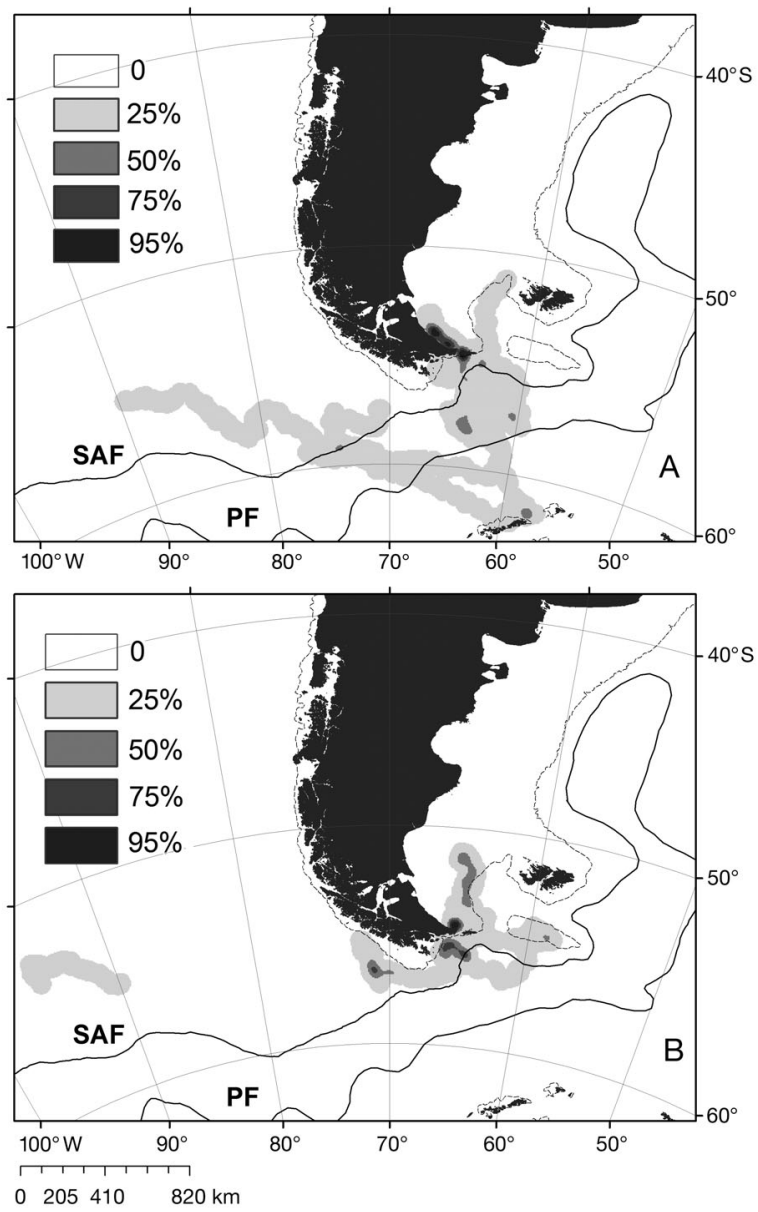

Fig. 1. Eudyptes chrysocome chrysocome. Kernel density contours of rockhopper penguin movements in 2002 (A) late autumn (March to May), (B) early winter (June to July). Dashed line marks the $200 \mathrm{~m}$ isobaths. SAF: Sub Antarctic Front; PF: Polar Front

the foraging activity of penguins was concentrated north of the Subantarctic Front: around the southern portion of the Chilean Tierra del Fuego, the Burdwood Bank and over the Patagonian shelf off Tierra del Fuego (Fig. 1b). In 2003, penguins also proceeded in different directions, but they foraged mainly close to the Atlantic coast of Tierra del Fuego during late autumn (Fig. 2a). In winter (June to August), they foraged near the Burdwood Bank and south of Staten Island close to the shelf break (Fig. 2b).

\section{Long-term temporal pattern}

A comparison of the average SST for the region (from latitude $40^{\circ}$ to $65^{\circ} \mathrm{S}$ and from longitude $40^{\circ}$ to $100^{\circ} \mathrm{W}$ ) for the study period indicated that ocean temperatures were colder in 2002 than the long-term average for the past $19 \mathrm{yr}\left(4.9 \pm 1.6^{\circ} \mathrm{C}\right.$ and $6.1 \pm 1.5^{\circ} \mathrm{C}$, for 2002 and the long-term, respectively; $t=-5.68$, $\mathrm{p}<0.001$ ). In comparison, the mean winter (March to August) values of SST were not significantly different from the long-term average $\left(6.05 \pm 2.5^{\circ} \mathrm{C}\right.$ and $6.1 \pm$ $\left.2.1^{\circ} \mathrm{C}\right)$ for 2003 and long-term, respectively $(t=-0.88$, $\mathrm{p}=0.391)$. However, this pattern was not mirrored in ocean production, because the chl a concentrations were not significantly different in $2002(0.6 \pm 0.6 \mathrm{mg}$ $\left.\mathrm{m}^{-3}\right)$ and $2003\left(0.6 \pm 0.4 \mathrm{mg} \mathrm{m}^{-3}\right)$ compared with the long-term average over the past $7 \mathrm{yr}$ (2002: $0.6 \pm$ $0.3 \mathrm{mg} \mathrm{m}^{-3}, t=-0.88, \mathrm{p}=0.403 ; 2003: 0.6 \pm 0.4 \mathrm{mg} \mathrm{m}^{-3}$, $t=-1.07, \mathrm{p}=0.3$ ). However, the latest conclusion should be taken with caution due to the scarce data for chl $a$ in 2002 .
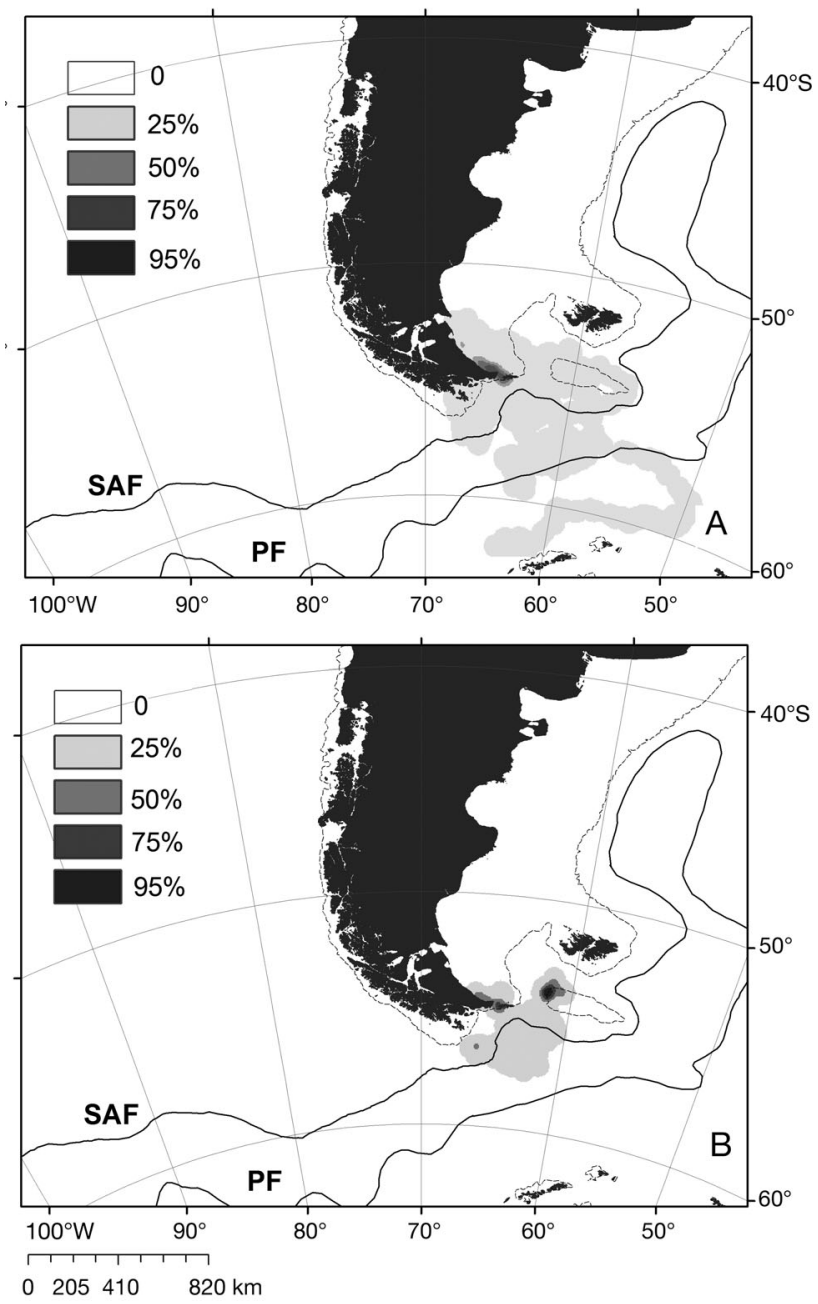

Fig. 2. Eudyptes chrysocome chrysocome. Kernel density contours of rockhopper penguin movements in 2003 (A) late autumn (March to May), (B) early winter (June to August). Dashed line marks the $200 \mathrm{~m}$ isobaths. SAF: Subantarctic Front; PF: Polar Front 
Table 3. Analysis of variation in SST, chl $a$ and $\log _{10}$-transformed bathymetry (hierarchical ANOVA) with contribution from year, month, kernel \% and interaction effects. Note: missing data for chl $a$ in 2002 leaves only $2 \mathrm{df}$ in the residual for testing differences between kernel percentages. Significant differences at $p<0.05$

\begin{tabular}{|c|c|c|c|c|c|c|c|c|c|}
\hline \multirow[t]{2}{*}{ Source } & \multicolumn{3}{|c|}{ SST } & \multicolumn{3}{|c|}{ Chl a } & \multicolumn{3}{|c|}{ Bathymetry } \\
\hline & $\mathrm{df}$ & $F$ & $\mathrm{p}$ & $\mathrm{df}$ & $F$ & $\mathrm{p}$ & $\mathrm{df}$ & $F$ & $\mathrm{p}$ \\
\hline Year & 1 & 8.88 & 0.041 & 1 & 0 & 1 & 1 & 0.84 & 0.41 \\
\hline Month & 4 & 3.46 & 0.183 & 4 & 1.62 & 0.33 & 4 & 0.82 & 0.57 \\
\hline Linear & 1 & 13.52 & $<0.001$ & 1 & 2.91 & 0.16 & 1 & 0.78 & 0.57 \\
\hline Non-linear & 3 & 0.11 & 0.76 & 3 & 1.19 & 0.42 & 4 & & \\
\hline Residual 1 & 4 & & & 4 & & & & & \\
\hline Between maps & 9 & & & 9 & & & 9 & & \\
\hline Percent & 3 & 10.27 & 0.002 & 3 & 311.49 & 0.003 & 3 & 9.95 & 0.001 \\
\hline Linear & 1 & 29.93 & $<0.001$ & 1 & 278.88 & 0.004 & 1 & 29.49 & $<0.001$ \\
\hline Non-linear & 2 & 0.44 & 0.66 & 2 & 174.56 & 0.006 & 2 & 0.2 & 0.82 \\
\hline Year $\times \%$ & 3 & 0.8 & 0.522 & 3 & 55.57 & 0.018 & 3 & 0.13 & 0.942 \\
\hline Month $\times \%$ & 12 & 1.98 & 0.143 & 12 & 57.73 & 0.017 & 12 & 0.94 & 0.543 \\
\hline Month $\times$ Linear & 4 & 4.45 & 0.025 & 4 & 132.16 & 0.008 & 4 & 2.45 & 0.1 \\
\hline Month $\times$ Non-linear & 8 & 0.75 & 0.65 & 8 & 20.48 & 0.047 & 8 & 0.18 & 0.99 \\
\hline Residual 2 & 10 & & & 2 & & & 12 & & \\
\hline Between kernel & 28 & & & 20 & & & 30 & & \\
\hline Total & 37 & & & 29 & & & 39 & & \\
\hline
\end{tabular}

\section{Short-term spatial and temporal pattern}

Spatial and temporal differences in oceanographic features were found in the habitat-use patterns of the rockhopper penguins during their winter dispersal in the 2 years studied. The penguins foraged in colder waters in $2002\left(5.09 \pm 1.67^{\circ} \mathrm{C}\right)$ compared to $2003(6.85 \pm$ $2.02^{\circ} \mathrm{C}$ ), which is consistent with the long-term SST dataset analysis. There was strong evidence for an effect of kernel percentage $(p=0.002)$, showing an increasing trend in the mean SST with increased kernel percentage. Penguins concentrated their foraging in waters from 5 to $8^{\circ} \mathrm{C}$ depending on the month (Tables $3 \& 4$ ), although no significant effect on month was apparent $(p=0.18)$. Also, there was little evidence of an effect of interaction between month and kernels $(p=0.14)$. However, there was strong evidence for a linear trend $(\mathrm{p}<0.001)$ when the variation was partitioned into linear and non-linear components within months (Table 3 ) and between month and kernel ( $\mathrm{p}=$ 0.025). The slope of the trend between kernels varied with month (Fig. 3). In general, and as expected, water temperatures of the foraging areas decreased as the winter progressed.

There were no differences between year $(p=1.00)$ or between months $(p=0.33)$ in ocean colour or the amount of chl $a$ in the areas used by penguins (Table 3 , Fig. 4). However, there were marked effects of kernels
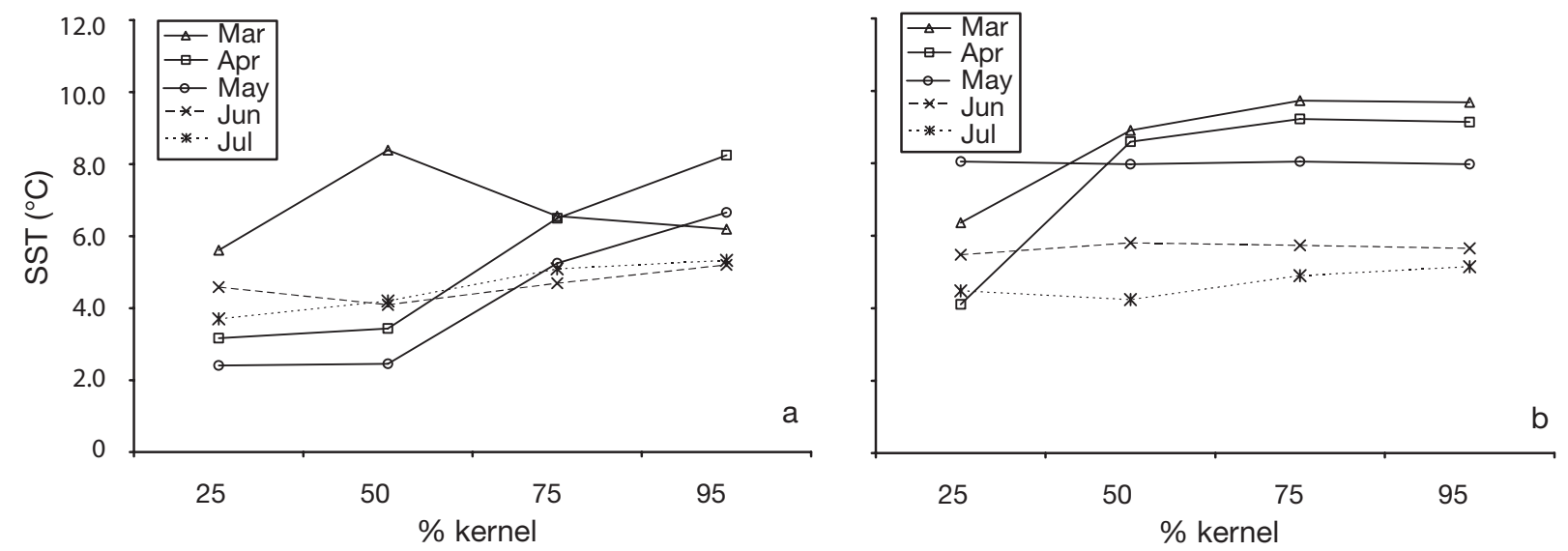

Fig. 3. Eudyptes chrysocome chrysocome. Sea surface temperature vs. kernel \% by month during the winter dispersal of rockhopper penguins in (a) 2002 and (b) 2003 

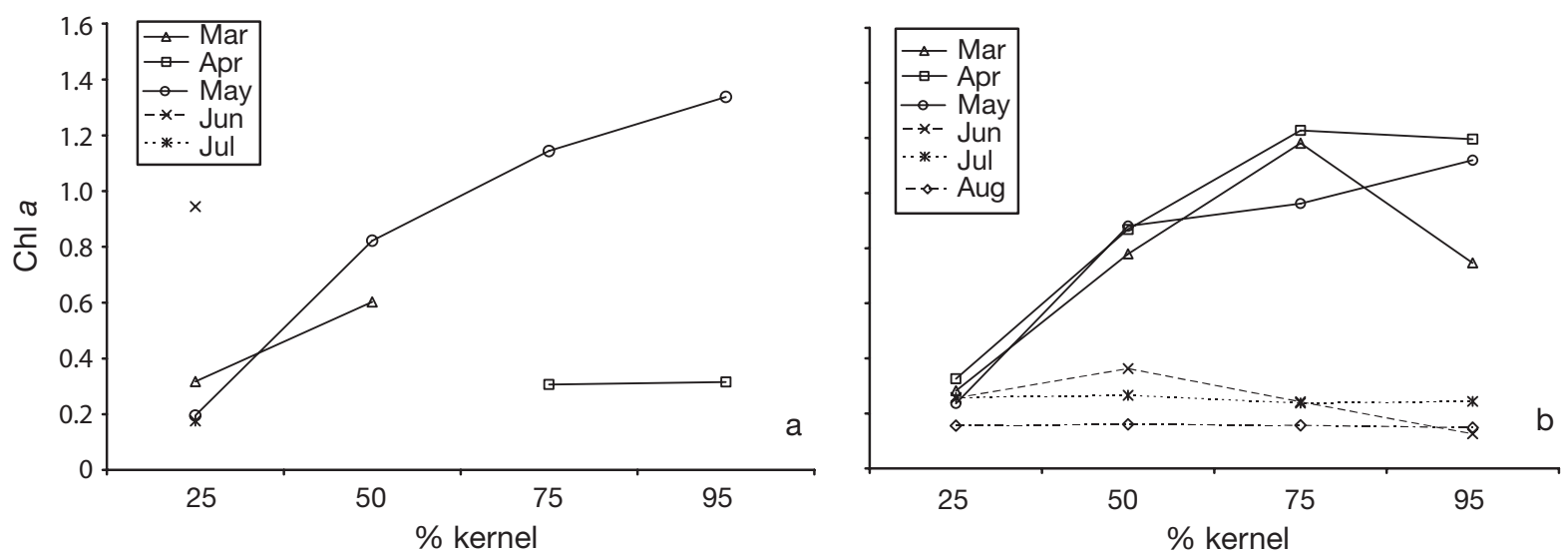

Fig. 4. Eudyptes chrysocome chrysocome. Chl a $\left(\mathrm{mg} \mathrm{m}^{-3}\right)$ vs. kernel \% by month during the winter dispersal of rockhopper penguins in (a) 2002 and (b) 2003. The missing data in 2002 is due to the different source of the image

$(\mathrm{p}=0.003)$, and the interaction with month $(\mathrm{p}=0.017)$. Again, for SST, much of the variation between kernels could be accounted for by a linear trend $(p=0.004)$ with a slope that varied between months $(p=0.008$, Table 3). In general, more productive areas were used at the beginning of the season and in core areas (Table 4, Fig. 4).

In terms of bathymetry in the foraging areas of the penguins, we found no differences between years $(p=0.41)$ or between months $(p=0.57)$ (Table 3$)$. However, as with the other oceanographic parameters, there was significant difference between kernels $(p=0.001$, Table 3$)$, with a linear trend accounting for most of the variation $(p<0.001)$. Foraging activity was concentrated in coastal or shelf areas of $<200 \mathrm{~m}$, whereas pelagic waters were used for migrating (25\%), with the exception of May 2002 and July to August 2003, which were without significant differences (Table 4, Fig. 5).
In 2002, the foraging areas of the penguins were characterised by strong SST gradients; during 2003, the birds occupied areas with much lower gradients (22.8 and $6.8 \%$ in 2002 and 2003, respectively; hierarchical ANOVA $F_{1,4}=10.67, \mathrm{p}<0.05$ ).

In a separate but concurrent study, we estimated the breeding success and return rate of adults using an automatic reading system with adults implanted with passive implantable transponders. The survival rate and breeding success were higher in 2002 to 2003 compared to the 2003 to 2004 breeding season ( 76 and $31 \%$ vs. 63 and $23 \%$, respectively.

\section{DISCUSSION}

Sea surface temperature is a fundamental factor driving biological variability in the marine ecosystem. For example, the relationship between sea surface

Table 4. Eudyptes chrysocome chrysocome. Values for different oceanographic parameters (mean $\pm \mathrm{SD}$ ) characterising spatial $(\%$ kernel) and temporal (month, values for $95 \%$ kernel) foraging activity of rockhopper penguins during their winter dispersal in 2002 and 2003. SST $\left({ }^{\circ} \mathrm{C}\right)$, chl a $\left(\mathrm{mg} \mathrm{m}^{-3}\right)$, bathymetry (m)

\begin{tabular}{|c|c|c|c|c|c|c|}
\hline & SST & $\begin{array}{l}2002 \\
\text { Chl a }\end{array}$ & Bathymetry & SST & $\begin{array}{l}2003 \\
\text { Chl a }\end{array}$ & Bathymetry \\
\hline \multicolumn{7}{|l|}{$\%$ kernel } \\
\hline 25 & $3.9 \pm 1.2$ & $0.4 \pm 0.3$ & $2608 \pm 558$ & $4.7 \pm 1.3$ & $0.2 \pm 0.05$ & $2472 \pm 1185$ \\
\hline 50 & $4.5 \pm 2.2$ & $0.7 \pm 0.1$ & $876 \pm 966$ & $5.9 \pm 2.8$ & $0.5 \pm 0.3$ & $1477 \pm 1827$ \\
\hline 75 & $5.6 \pm 0.8$ & $0.7 \pm 0.5$ & $524 \pm 663$ & $6.6 \pm 2.9$ & $0.6 \pm 0.5$ & $1398 \pm 1941$ \\
\hline 95 & $6.3 \pm 1.2$ & $0.8 \pm 0.7$ & $126 \pm 131$ & $6.7 \pm 2.7$ & $0.5 \pm 0.5$ & $903 \pm 1779$ \\
\hline \multicolumn{7}{|l|}{ Month } \\
\hline March & $6.2 \pm 3.3$ & $0.3 \pm 0.02$ & $720 \pm 1044$ & $9.7 \pm 0.3$ & $0.7 \pm 0.5$ & $535 \pm 998$ \\
\hline April & $8.2 \pm 0.4$ & $1.3 \pm 0.9$ & $278 \pm 499$ & $9.1 \pm 0.4$ & $1.2 \pm 0.8$ & $173 \pm 391$ \\
\hline May & $6.7 \pm 0.6$ & & $3724 \pm 1016$ & $8.0 \pm 1.4$ & $1.1 \pm 0.8$ & $248 \pm 527$ \\
\hline June & $5.2 \pm 0.3$ & & $2573 \pm 1595$ & $5.7 \pm 0.5$ & $0.1 \pm 0.1$ & $210 \pm 50$ \\
\hline July & $5.3 \pm 0.3$ & & $531 \pm 1097$ & $5.2 \pm 0.3$ & $0.2 \pm 0.1$ & $3952 \pm 161$ \\
\hline
\end{tabular}



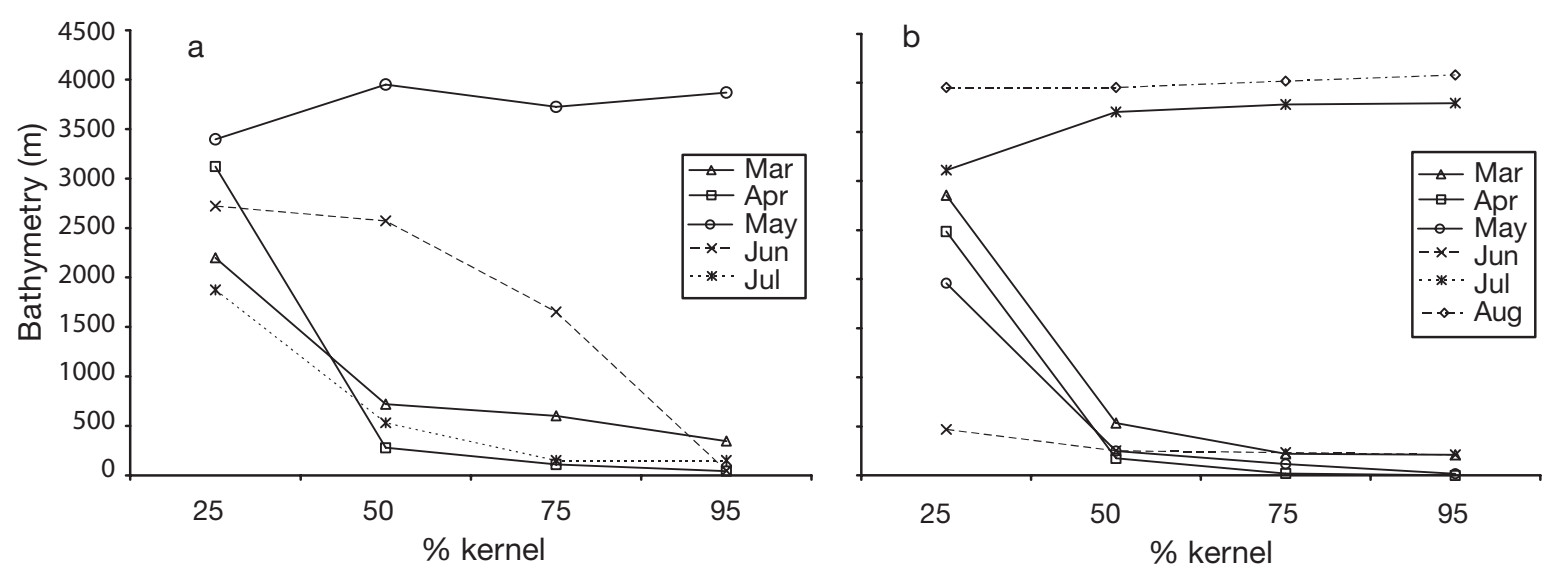

Fig. 5. Eudyptes chrysocome chrysocome. Bathymetry vs. kernel \% by month during the winter dispersal of rockhopper penguins in (a) 2002 and (b) 2003

temperature and lower trophic level species has been documented with a higher abundance of krill during anomalously cold periods (Trathan et al. 2003), while lower recruitment of squid (Waluda et al. 1999, 2004) and fish (North et al. 1998, North 2005) have been linked to warmer oceanic conditions. Therefore, top predators will presumably also be affected by climate variability, if such variability is linked to changes in food availability. Thus, physical variability in the marine environment can potentially be used to predict responses in higher trophic-level predator dynamics (Trathan et al. 2006). Further, Abraham \& Sydeman (2004) showed that Cassin's auklets Ptychoramphus aleuticus responded adaptively to variation in oceanographic conditions and prey availability by modifying time of breeding.

In our study we found little difference in oceanographic variables within the foraging areas of rockhopper penguins during their dispersal in 2 winters. However, we did find contrasting foraging behaviour, in terms of the number and size of core areas used, in years with different oceanographic conditions and some evidence of an effect on breeding success and adult survival. Unfortunately, the number of birds, and therefore the number of positions for the later months, are relatively few (Table 2 ).

The spatial and temporal distribution of the penguins varied little within the oceanographic parameters. We found spatial differences in the 3 oceanographic features. In general, the foraging areas were characterized by a higher mean sea surface temperature, higher chl a concentration and a tendency to shallow and shelf slope rather than oceanic waters, compared with the areas of migration. However, we found no differences in the year and percent interaction and only a linear trend (to lower values) in the parameters as winter progressed. This result could indicate that penguins foraged in a certain range of the oceanographic parameters possibly related to favourable conditions for their prey in each month. It is well known that the distribution of planktonic and nektonic species depend on water temperature (Hulley 1981, Hosie el al. 2003).

Several factors associated with regional warming have been suggested as possible causes of seabird declines, even though seabird populations show different dynamic responses to environmental variability (Croxall et al. 2002). Inchausti et al. (2003) showed that warm sea surface temperature-anomalies in the Southern Indian Ocean affected differently the breeding success of seabirds, depending on where each group foraged. Adult mortality among southern fulmars Fulmarus glacialoides increased in years with high winter sea surface temperature and low winter sea ice concentration, while having a lesser impact during the breeding season (Jenouvrier et al. 2003). Moreover, the fluctuation in the proportion of breeders had a strong impact on the population dynamics of southern fulmar, and thus Jenouvrier et al. (2003) predicted a high rate of population decline. The reproductive performance of gentoo penguins Pygoscelis papua and Antarctic fur seals Arctocephalus gazella varied markedly between years, and some years of extremely low reproductive output were linked with sea surface temperature prior to the breeding season (Forcada et al. 2005, Trathan et al. 2006). Moreover, these aboveaverage sea surface temperatures were preceded by, and cross-correlated with, frequent El Niño-La Niña events (Trathan \& Murphy 2002, Forcada et al. 2005).

Populations of southern rockhopper penguins have decreased dramatically in the Falkland (Malvinas) Islands, where a decline of more than $80 \%$ has been recorded (Pütz et al. 2003). Comparable population declines of rockhopper penguins were noted for the 
other subspecies throughout the Southern Ocean (Moors 1986, Cooper 1992, Cooper et al. 1997, Ellis et al. 1998, Guinard et al. 1998). The reasons for such declines remain unclear, although concurrent changes in sea surface temperature are potentially linked to reduced food availability (Cunningham \& Moors 1994, Guinard et al. 1998). In contrast to the trend found in the Falkland (Malvinas) Islands, the population from Staten Island appears to be increasing or stable, at least since the 1970s (Schiavini 2000). However, there are no long-term data on the population parameters for rockhopper penguins from Staten Island and so levels of variability and a trend from this colony remain uncertain. Recently, Pütz et al. (2006) showed that the winter-foraging areas of both populations only marginally overlapped and suggested that the differences in population trends may be related to differences in human activities within preferred winter-foraging areas. Recent events indicate that rockhopper penguins in the Falkland Islands have continued to decline. In 2002, large numbers of rockhopper penguins died in the Falkland Islands probably due to starvation prior to, or immediately after, moult, because of a food shortage in the southwest Atlantic (Huin 2002). This phenomenon was not observed at Staten Island in 2002 (A. Raya Rey pers. obs.). The results presented here suggest that biological factors driven by physical variability in the different foraging areas may contribute to the different trends found in rockhopper penguin populations apart from the anthropogenic factors in Pütz et al. (2006).

In this study, we found differences in the oceanographic conditions in the 2 winters; 2002 was a colder than average year, while SST in 2003 was very similar to the long-term average. Given the higher SST percentage of gradient cells within the 2002 foraging area, it seems that in the 2002 winter the oceanographic conditions were much more heterogeneous than in the 2003 winter. Thermal ocean gradients are generally accompanied by salinity and density gradients (Park et al. 1998). Discontinuities in physical properties of the water column may result in enhanced biological activity because of the 'barrier effect' of the density gradients (Boyd \& Arnbornd 1991). The foraging areas used by the penguins in the 2 years seemed to be affected by those differences. In both years, the penguins proceeded in different directions, and in 2002 they used more than one foraging area. This indicates that in 2003 penguins were probably not able to find food patches in their usual foraging areas and therefore spent more time travelling. Moreover, we found differences in adult survival or return rate and breeding success in the following breeding season of each winter studied. In colder winters with more heterogeneous oceanographic conditions (such as 2002), the penguins may have been able to find enough food to achieve better body condition for the following breeding season, as was also suggested for gentoo penguins and Antarctic fur seals breeding at Bird Island, South Georgia (Trathan et al. 2006). Moreover, differences in foraging areas were more pronounced during late autumn (March to May), and given the differences in breeding parameters, we suggest that this particular period represents a critical time for rockhopper penguins. Late autumn and early winter were critical times for Adélie penguins, while early winter was important for chinstrap penguins (Trathan et al. 1996). However, since there are no previous data on breeding parameters for rockhopper penguins from Staten Island, we cannot absolutely verify that the differences in breeding parameters were not within normal variability for this population.

The results presented here are based on a short-term study. Long-term data are required to understand fully how the physical and biological variability in the environment of penguins affects their demographic processes. In addressing this, several datasets are required: long-term studies of penguin population dynamics, knowledge about the diet during the wintertime as well as a complementary study on the influence of the physical variability on penguin prey.

Acknowledgements. This research was possible with the support of the Consejo Nacional de Investigaciones Científicas y Técnicas (CONICET) and many individual donations to the Antarctic Research Trust. Special thanks to Nautilus SA and Antarpply SA for transportation to Staten Island under difficult weather conditions and to several people who helped with the fieldwork. We thank A. Fleming from the British Antarctic Survey (BAS) for providing the oceanographic data. A.R.R. particularly thanks John Croxall for his support and advice during her $\mathrm{PhD}$ studies, and all the people from BAS, especially Janet Silk.

\section{LITERATURE CITED}

Abraham CL, Sydeman WJ (2004) Ocean climate, euphausiids and auklet nesting: inter-annual trends and variation in phenology, diet and growth of a planktivorous seabird, Ptychoramphus aleuticus. Mar Ecol Prog Ser 274:235-250

Argos (1996) User's manual. CLS Service Argos, Toulouse

Atkinson A, Siegel V, Pakhomov E, Rothery P (2004) Longterm decline in krill stock and increase in salps within the Southern Ocean. Nature 432:100-103

Bannasch R, Wilson RP, Culik BM (1994) Hydrodynamic aspects of design and attachment of a back-mounted device in penguins. J Exp Biol 194:83-96

Barbraud C, Weimerskirch H (2001) Emperor penguins and climate change. Nature 411:183-186

Bertram DF, Harfenist A, Smith BD (2005) Ocean climate and El Niño impacts on survival of Cassin's Auklets from upwelling and downwelling domains of British Columbia. Can J Fish Aquat Sci 62:2841-2853

Boyd IL, Arnbornd T (1991) Diving behaviour in relation to water temperature in the southern elephant seal: foraging 
implications. Polar Biol 11:259-266

Brodie PF, Sameoto DD, Sheldon RW (1978) Population densities of euphausiids off Nova Scotia as indicated by net samples, whale stomach contents and sonar. Limnol Oceanogr 23:1264-1267

Cooper J, Wolfaardt A, Crawford RJM (1997) Trends in size and success of breeding colonies of Macaroni and Rockhopper penguins at Marion Island, 1979/80-1995/96. CCAMLR Science 4:125-147

Cooper W (1992) Rockhopper penguins at the Auckland Islands. Notornis 39:66-67

Croxall JP, Trathan PN, Murphy EJ (2002) Environmental change and Antarctic seabird populations. Science 297: $1510-1514$

Cunningham DM, Moors PJ (1994) The decline of Rockhopper penguins Eudyptes chrysocome at Campbell Island, Southern Ocean and the influence of rising sea temperatures. Emu 94:27-36

Daunt F, Peters G, Scott B, Gremillet D, Wanless S (2003) Rapid-response recorders reveal interplay between marine physics and seabird behaviour. Mar Ecol Prog Ser 255:283-288

Ellis S, Croxall JP, Cooper J (eds) (1998) Penguin conservation assessment and management plan. IUCN/SSC Conservation Breeding Specialist Group Apple Valley, MN. Available at: www.cbsg.org/reports/camp.php

Forcada J, Trathan PN, Reid K, Murphy EJ (2005) The effects of global climate variability in pup production of Antarctic seals. Ecology 86:2408-2417

Forcada J, Trathan PN, Reid K, Murphy EJ, Croxall JP (2006) Contrasting population changes in sympatric penguin species with climate warming. Global Change Biol 12: 411-423

Frederiksen M, Wanless S, Harris MP, Rothery P, Wilson LJ (2004) The role of industrial fisheries and oceanographic change in the decline of North Sea black-legged kittiwakes. J Appl Ecol 41:1129-1139

Guinard E, Weimerskirch H, Jouventin P (1998) Population changes of the Northern Rockhopper penguin on Amsterdam and Saint Paul Islands. Colon Waterbirds 21:222-228

Guinet C, Dubroca L, Lea MA, Goldsworthy S, Cherel Y, Duhamel G, Bonadonna F, Donnay JP (2001) Spatial distribution of foraging in female Antarctic fur seals Arctocephalus gazella in relation to oceanographic variables: a scale-dependent approach using geographic information systems. Mar Ecol Prog Ser 219:251-264

Hosie GW, Fukuchi M, Kawaguchi S (2003) Development of the Southern Ocean Continuous Plankton Recorder survey. Prog Oceanogr 58:263-283

Huin N (2002) Dead penguins present complicated problem. Falklands Conservation Newsletter May 2002

Hull CL (1996) Morphometric indices for sexing adult Royal Eudyptes schlegeli and Rockhopper E. chrysocome Penguins at Macquarie Island. Mar Ornithol 24:23-27

Hulley PA (1981) Results of the research cruise of FRV 'Walter Herwig' to South America. LVIII family Myctophidae (Osteicthyes, Myctophiformes). Archiv Fischereiwiss 42: $1-300$

Hyrenbach KD, Fernández P, Anderson DJ (2002) Oceanographic habitats of two sympatric North Pacific albatrosses during the breeding season. Mar Ecol Prog Ser 233: 283-301

Inchausti P, Guinet C, Koudil M, Durbec JP, Barbraud C, Weimerskirch H, Cherel Y, Jouventin P (2003) Interannual variability in the breeding performance of seabirds in relation to oceanographic anomalies that affect the Crozet and the Kerguelen sectors of the Southern Ocean.
J Avian Biol 34:170-176

Jahncke J, Coyle KO, Zeeman SI, Kachel NB, Hunt GL Jr (2005) Distribution of foraging shearwaters relative to inner front of SE Bering Sea. Mar Ecol Prog Ser 305:219-233

Jenouvrier S, Barbraud C, Weimerskirch H (2003) Effects of climate variability on the temporal population dynamics of southern fulmars. J Anim Ecol 72:576-587

Jenouvrier S, Barbraud C, Cazelles B, Weimerskirch H (2005) Modelling population dynamics of seabirds: importance of the effects of climate fluctuations on breeding proportions. Oikos 108:511-522

Ladd C, Jahncke J, Hunt GL, Coyle KO, Stabeno PJ (2005) Hydrographic features and seabird foraging in Aleutian Passes. Fish Oceanogr 14:178-195

McConnell BJ, Chambers C, Fedak MA (1992) Foraging ecology of southern elephant seals in relation to bathymetry and productivity of the Southern Ocean. Antarct Sci 4: 393-398

Moore JK, Abbott MR, Richman JG (1997) Variation in the location of the Antarctic Polar Front $\left(90-20^{\circ} \mathrm{W}\right)$ from satellite sea surface temperature data. J Geophys Res Oceans 102:27825-27833

Moors PJ (1986) Decline in numbers of rockhopper penguins at Campbell Island. Polar Record 23:69-73

Nel DC, Lutjeharms JRE, Pakhomov EA, Ansorge IJ, Ryan PG, Klages NTW (2001) Exploitation of mesoscale oceanographic features by grey-headed albatross Thalassarche chrysostoma in the southern Indian Ocean. Mar Ecol Prog Ser 217:15-26

North AW (2005) Mackerel icefish size and age differences and long-term change at South Georgia and Shag Rocks. J Fish Biol 67:1666-1685

North AW, White MG, Trathan PN (1998) Interannual variability in the early growth rate and size of the Antarctic fish Gobionotothen gibberifrons (Lonnberg). Antarctic Sci 10:416-422

Park YH, Charriaud E, Fieux M (1998) Thermohaline structure of the Antarctic surface water/winter water in the Indian sector of the Southern Ocean. J Mar Syst 17:5-23

Pütz K, Smith JG, Ingham RJ, Lüthi BH (2002) Winter dispersal of rockhopper penguins Eudyptes chrysocome from the Falkland Islands and its implications for conservation. Mar Ecol Prog Ser 240:273-284

Pütz K, Clausen AP, Huin N, Croxall JP (2003) Re-evaluation of historical rockhopper penguin population data in the Falkland Islands. Waterbirds 26:169-175

Pütz K, Raya Rey A, Schiavini A, Clausen AP, Lüthi BH (2006) Winter migration of Rockhopper Penguins (Eudyptes C. chrysocome) from Staten Island, Argentina. Polar Biol 29:735-744

Schiavini ACM (2000) Staten Island, Tierra del Fuego: the largest breeding ground for Southern rockhopper penguins? Waterbirds 23:286-291

Schreiber EA (2001) Climate and weather effects on seabirds. In: Schreiber EA, Burger J (eds) Biology of marine birds. CRC Press, Boca Raton, FL, p 179-207

Trathan PN, Croxall JP (2004) Marine predators at South Georgia: an overview of recent bio-logging studies. Mem Natl Inst Polar Res (Spec Iss) 58:118-132

Trathan PN, Murphy EJ (2002) Sea surface temperature anomalies near South Georgia: relationships with the Pacific El Niño regions. J Geophys Res 108: C4, 8075, doi:10.1029/2000JC000299

Trathan PN, Croxall JP, Murphy EJ (1996) Dynamics of Antarctic penguin populations in relation to inter-annual variability in sea ice distribution. Polar Biol 16:321-330

Trathan PN, Brierly AS, Brandon MA, Bone DG, Goss C, Grant 
SG, Murphy EJ, Watkins JL (2003) Oceanographic variability and changes in Antarctic krill (Euphausia superba) abundance at South Georgia. Fish Oceanogr 12:569-583

Trathan PN, Murphy EJ, Forcada J, Croxall JP, Reid K, Thorpe SE (2006) Physical forcing in the southwest Atlantic: ecosystem control. In: Boyd IL, Wanless S, Camphuysen CJ (eds) Top predators in marine ecosystems. Cambridge University Press, Cambridge, p 28-45

Waluda CM, Trathan PN, Rodhouse PG (1999) Influence of oceanographic variability on recruitment in the Illex argentinus (Cephalopoda: Ommastrephidae) fishery in the South Atlantic. Mar Ecol Prog Ser 183:159-167

Waluda CM, Trathan PN, Rodhouse PG (2004) Synchronicity

Editorial responsibility: Howard Browman (Associate Editorin-Chief), Storebø, Norway in southern hemisphere squid stocks and the influence of the Southern Oscillation and Trans Polar Index. Fisheries Oceanogr 13:1-12

Wilson RP, Pütz K, Peters G, Culik B, Scolaro JA, Charrassin JB, Ropert-Coudert Y (1997) Long-term attachment of transmitting and recording devices to penguins and other seabirds. Wildl Soc Bull 25:101-106

Wilson RP, Kreye JM, Lucke K, Urquhart H (2004) Antennae on transmitters on penguins: balancing energy budgets on the high wire. J Exp Biol 207:2649-2662

Xavier JC, Croxall JP, Trathan PN, Wood AG (2003) Feeding strategies and diets of breeding grey-headed and wandering albatrosses at South Georgia. Mar Biol 143:221-232

Submitted: December 22, 2005; Accepted: May 9, 2006 Proofs received from author(s): January 2, 2007 